\title{
Assessing the Indoor Pollutants Effect on Ornamental Plants Leaves by FT-IR Spectroscopy
}

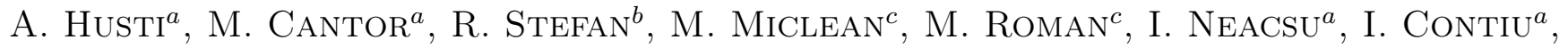 \\ K. MAGYARI ${ }^{d, e}$ AND M. BAIA ${ }^{d, e *}$ \\ ${ }^{a}$ Faculty of Horticulture, University of Agricultural Sciences and Veterinary Medicine, \\ Manastur 3-5, 400372 Cluj-Napoca, Romania \\ ${ }^{b}$ Faculty of Veterinary Medicine, University of Agricultural Sciences and Veterinary Medicine, \\ Manastur 3-5, 400372, Cluj-Napoca, Romania \\ ${ }^{c}$ Research Institute for Analytical Instrumentation, Donath 67, 400293 Cluj-Napoca, Romania \\ ${ }^{d}$ Institute for Interdisciplinary Research in Bio-Nano-Sciences, Babes-Bolyai University, \\ T. Laurian 42, 400271, Cluj-Napoca, Romania \\ ${ }^{e}$ Faculty of Physics, Babes-Bolyai University, M. Kogalniceanu 1, 400084, Cluj-Napoca, Romania
}

(Received July 28, 2015)

\begin{abstract}
Air pollution has become a mass phenomenon, a major and global problem of modern society, affecting billions of people and environment. People are exposed to various levels of pollutants not just in the outdoor environment, but also in indoors. The quality of life and well-being of employees can be increased by incorporating ornamental plants in the work environment. Among the great variety of plants species able to remove/reduce indoor air pollutants Dracaena deremensis, Sansevieria trifasciata and Ficus elastica were hereby investigated. Their ability to remove chemical pollutants was evaluated in real-life conditions and the changes induced by the environmental stress on the structure and biochemical composition of the plants leaves were evidenced by the Fourier transform infrared spectroscopy. The most pronounced concentration decrease was noticed for the $\mathrm{CO}_{2}(58.33 \%$ removed concentration), whereas the mean value of the removed concentration of other chemical pollutants was of $\approx 25 \%$. The Fourier transform infrared spectra analysis revealed that, although the plants are subjected to the chemical pollutants action, they maintain the structure by adjusting their metabolism. A decrease in the overall protein contribution in the amide bands and an increase of the bands assigned to polysaccharide vibrations, illustrate the consequences of the pollution action. Moreover, the chlorophyll presence is evidenced in the IR spectra of all samples by the bands around 1040, 1445, 1620, and $1735 \mathrm{~cm}^{-1}$. The results show that the Fourier transform infrared spectra are an important source of information for the rapid characterization of the chemical structure of the biological systems under environmental stress.
\end{abstract}

DOI: 10.12693/APhysPolA.129.142

PACS: 87.14.--g, 87.15.B-, 87.64.km, 92.60.Sz

\section{Introduction}

Among the critical, various challenges and diversity of problems facing modern society can be found also air pollution [1], a release environmental issue. At all levels of economic development, pollution is considered one of the most crucial and serious environmental problems [2]. Air pollution, is a global aspect that affects, and is responsible for the harmful consequences that it has on human health, natural ecosystems, animal life and anthropic environment. Air quality degradation is due to air pollution and threatens human well-being and quality of life.

Not just in the outdoor environment, but also in the interior people are exposed to various levels of pollutants. If outdoor air pollution until recently was considered the main problem with regard to air quality, things have changed due to lifestyle imposed by modern society, becoming a serious problem as well. In recent decades,

*corresponding author; e-mail: monica.baia@phys.ubbcluj.ro the working environment has changed gradually from factories to offices, due to the global transition from manufacturing to services. Therefore, the number of people working in office buildings has increased and thus requires an increase in the understanding of potential health hazards related to closed environments such as work offices. Contemporary society must identify the need to change the way of thinking about human activities, highlighting practices that support and protect the environment. A decisive challenge for society is precisely the adoption of sustainable practices daily [3].

Indoor air pollution is pervasive, and takes many forms. Occupants of interior spaces are usually exposed to a wide variety of pollutants. The main pollutants that can be traced in any indoor space and contribute to poor air quality include carbon monoxide, $\mathrm{CO}_{2}$, formaldehyde, benzene, nitrogen oxides, sulfur oxides, toxic metals, polycyclic aromatic compounds, particulate matter and volatile organic compounds (VOC) $[4,5]$. VOC pollutants are the most spread class of chemical compounds [6] that affect indoor air quality. The VOC term refers to any compound of carbon with a relatively high vapor 
pressure at room temperature. According to Wolkoff [6] VOC are often recognized as odors, even before reaching levels that could endanger human health, thus contributing to the perception of indoor air quality. Formaldehyde and methane are sources of VOC. Possible effects of indoor air pollution on human health have become a crucial problem of international concern [6, 7]. Formaldehyde, for example, can provoke irritation and cancer at nasal and pharyngeal level. As World Health Organization recommends [5], the guideline concentration value for $30 \mathrm{~min}$ exposure is $0.1 \mathrm{mg} / \mathrm{m}^{3}$.

As a non-invasive and low cost method to increase the quality of life and well-being of employees, companies could incorporate in the work environment design ornamental plants. It is well documented that plants in indoor space not only add aesthetic value, but contribute and promote the improvement of indoor air quality $[8,9]$. Likewise, ornamental plants can be effectively used as bioindicators of air quality [10-12]. The most sensitive part of the plant is leaf, and therefore, it is affected by air pollutants. Leaves play a major role in the absorption and accumulation of air pollutants to reduce the level of pollutants [13]. The mechanism by which plants reduce or remove indoor air pollutants is done mainly through leaf stomata and after they have penetrated the leaf, in the intercellular spaces the gases are distributed and absorbed by water films [14].

Ornamental plants species with the ability to remove or reduce indoor air pollutants are more than 100 and include: Dracaena spp. [15, 16], Sansevieria trifasciata [17], Ficus spp. [18], Schefflera spp. [19], Spatiphyllum spp. [20, 21], Orchids, Hedera helix [22, 23], Dieffenbachia spp., Epipremnum spp. [24, 25], Nerium indicum [26], etc. Usually, the experiments conducted in order to assess the plants ability for pollutants removal are carried out in laboratories with closed chambers and pollutants injection into the chamber, most of them using $\mathrm{CO}_{2}$, formaldehyde and trichloroethylene as test chemical pollutants $[27,28]$. Just a few studies were conducted in real-life indoor settings by comparing the level of pollutants from offices with and without plants [29], or continuous integration of different plants in the offices [30] and combination of plants introduction in indoor space and ventilation [31].

In recent years, the Fourier transform infrared (FT-IR) technique has been broad applied in the area of environment and pollution monitoring [32]. In the case of environmental studies FT-IR spectroscopy is used to analyze relevant amount of compositional and structural information concerning environmental samples [33]. It is also known [34] that FT-IR spectroscopic method is successfully applied to the analysis of valuable plant substances because it allows the obtaining of spectra that contain fingerprint bands of individual components. However, none of the mentioned studies concerning the evaluation of the plant's capability to remove pollutants have used FT-IR analysis for plants investigations.

Even though the area of research studies is ample, with many plant species, in the present study, the interest is focused on in three species: Ficus elastica, Dracaena deremensis and Sansevieria trifasciata. The plants have been selected mainly for their ability to purify the air, as well as other factors, such as the low maintenance requirements of light, the size, shape and general aesthetic qualities [35-37]. The present study was conducted in a real-life indoor environment, more specifically in a company office. Thus, the plant ability to remove chemical pollutants, different from those usually employed as test molecules in laboratory experiments, is assessed. The study undertook not only biometric measurements and determinations of air pollutants removed concentrations, but also FT-IR analysis of the individual plants, more exactly of their leaves, in order to get detail about the structural changes induced by the environmental stress.

\section{Experimental}

Biological material consists on leaves, collected from three ornamental species: Ficus elastica, Dracaena deremensis and Sansevieria trifasciata. These were arranged in two experimental variants:

V1 - plants maintained in a company clean office (without employees, electronic devices, etc.), that will be further denoted as unpolluted plants and will be considered the control samples;

$\mathrm{V} 2$ - plants maintained in a company polluted office (with employees, electronic devices, etc.) that will be further denoted as polluted plants.

The plants were maintained for 2 months in both unpolluted and polluted environments and the collected leaves from the plant species were further subjected to FT-IR investigations.

The biometric measurements were carried out weekly on all plants. The measured plant parameters were height, diameter and number of leaves per plant, in accordance with the parameters assessed in the study conducted by Holcman and Sentelhas [38]. The measurements of the height of the plant were carried out from the level of the soil surface to the apex of the largest shoots for the individual plants [39].

For detection of air pollutants the following equipments were used: Testo 350 XL, Thermo-FID PT, TDGC-MS Agilent Technologies. In the ambient environment there were identified various pollutants such as: $\mathrm{CO}_{2}$, butyraldehyde, formaldehyde, $\mathrm{O}_{3}$, toluene, xylene, ethylbenzene, etc. The concentrations of all chemical pollutants determined at the beginning and at the end of the test period are summarized in Table I.

FT-IR spectra were recorded with a JASCO IRT5000 microscope coupled with a JASCO FTIR-6000 spectrometer in reflection configuration in the range $4000-700 \mathrm{~cm}^{-1}$ with a resolution of $4 \mathrm{~cm}^{-1}$, using the $32 \times$ Cassegrain objective to image a sample area of $\approx 50 \times 50 \mu \mathrm{m}^{2}$. Spectra were recorded at the cuticle level of the leaves. Fine section from the surface of the leaves was taken by using a sterilized thin blade and placed under the microscope. 
Air pollutants removal by ornamental plants with the recommended concentration values by WHO and AGÖF (2013) for $8 \mathrm{~h}$ exposure*.

\begin{tabular}{|c|c|c|c|c|c|c|}
\hline \multirow{2}{*}{$\begin{array}{l}\text { Chemical } \\
\text { pollutant }\end{array}$} & "normal & attention & recomm. & \multicolumn{2}{|c|}{ Test values ${ }^{* *}\left[\mu \mathrm{g} / \mathrm{m}^{3}\right]$} & \multirow{2}{*}{$\begin{array}{c}\text { Removed } \\
\text { concentr. [\%] }\end{array}$} \\
\hline & \multicolumn{3}{|c|}{ value $\left[\mu \mathrm{g} / \mathrm{m}^{3}\right]$} & beginning & end & \\
\hline $\mathrm{CO}_{2}$ & - & - & 1800.0 & 1649.0 & 687.0 & 58.33 \\
\hline butyraldehyde & 2.0 & 10.0 & 44.0 & 43.18 & 33.2 & 23.11 \\
\hline formaldehyde & 35.0 & 81.0 & $50 / 30.0$ & 36.57 & 26.1 & 28.63 \\
\hline $\mathrm{O}_{3}$ & - & - & 100.0 & 15.11 & 11.6 & 23.22 \\
\hline toluene & 7.0 & 30.0 & 15.0 & 14.97 & 11.5 & 23.17 \\
\hline $\mathrm{m}$,p-xylene & 3.0 & 29.0 & 29.0 & 12.37 & 8.8 & 28.86 \\
\hline o-xylene & 1.0 & 9.0 & 9.0 & 9.25 & 7.1 & 23.24 \\
\hline limonene & 4.0 & 23.0 & 4.0 & 4.09 & 2.9 & 29.09 \\
\hline benzene & 1.0 & 3.0 & 3.0 & 3.6 & 2.5 & 30.55 \\
\hline ethylbenzene & 1.0 & 10.0 & 10.0 & 3.25 & 2.3 & 29.23 \\
\hline 2-methylpentane & 1.0 & 7.9 & 7.0 & 3.09 & 2.2 & 28.8 \\
\hline n-hexane & 1.8 & 8.0 & 8.0 & 3.08 & 2.2 & 28.57 \\
\hline dodecane & 1.0 & 9.0 & 9.0 & 2.75 & 2.1 & 23.63 \\
\hline $\mathrm{SO}_{2}$ & - & - & 20.0 & 1.07 & 0.8 & 25.23 \\
\hline methylcyclopentane & $<1$ & 3.0 & 3.0 & 0.41 & 0.3 & 26.82 \\
\hline
\end{tabular}

${ }^{*}$ WHO - World Health Organization, AGÖF - Association of Ecological Research Institutes, Germany.

${ }^{* *}$ Test values represent the values of the pollutants concentration determined at the beginning and at the end of the test period (after 2 months).

\section{Results and discussion}

As mentioned above the concentrations of all chemical pollutants, which were identified in the indoor environment, determined at the beginning and at the end of the test period are summarized in Table I. By analyzing the data presented in Table I one can observe that the pollutants concentration from the office decreased at the end of the test period in the plant's presence. The most pronounced decrease was noticed for the $\mathrm{CO}_{2}$ concentration (58.33\% removed concentration), but this result is not surprising at all, because the plants use $\mathrm{CO}_{2}$ for the photosynthesis reaction. As it was already mentioned [27, 28] most of the studies carried out in laboratory are evaluating the plants ability to remove $\mathrm{CO}_{2}$, formaldehyde and trichloroethylene, used as test pollutant molecules. In this case, by performing the investigations in real-life conditions the plants' capacity to remove a large variety of pollutants was evaluated. The removed concentration of the chemical pollutants from the work office by ornamental plants is also presented in Table I. Among the chemical pollutants which experienced the best removed concentration after $\mathrm{CO}_{2}$, one remarks benzene, ethylbenzene, limonene, 2-methylpentane, formaldehyde, xylene with a removal concentration percentage of around $28 \%$. One should also mention that the mean value of the concentration removal percent of all chemical pollutants identified in the office was of $\approx 25 \%$.

Plants in order to face the stressor have developed different mechanisms [40]. Polluting gases such as $\mathrm{SO}_{2}$ and $\mathrm{NO}_{x}$ enter leaves through stomata, following the same diffusion pathway as $\mathrm{CO}_{2}$. In some cases, the exposure to pollutant gases (e.g. $\mathrm{SO}_{2}$ ) causes stomatal closure, which protects the leaf against further entry of the pollutant, but also curtails photosynthesis. In the cells, $\mathrm{SO}_{2}$ dissolves to give bisulfite and sulfite ions, which are effectively detoxified by plants at sufficiently low concentrations, and thus, $\mathrm{SO}_{2}$ air pollution provides a sulfur source for the plant [41].

Ozone is a highly reactive pollutant, which binds to plasma membranes and alters the metabolism of the plants. As a consequence, stomatal apertures are poorly regulated, chloroplast thylakoid membranes are damaged, rubisco is degraded, and photosynthesis is inhibited [42]. Ozone reacts with $\mathrm{O}_{2}$ and produces reactive oxygen species, that denature proteins and damage nucleic acids (thereby giving rise to mutations), and also cause lipid peroxidation, which breaks down lipids in membranes [42]. Cells are protected, at least in part, from reactive oxygen species by enzymatic and nonenzymatic defense mechanisms [43]. Thus, the exposure of plants to reactive oxygen species stimulates the transcription and translation of genes that encode enzymes involved in protection mechanisms [41].

Plants have the ability to develop various anatomical structures of protection, such as thick cuticle of leaves. In addition, stress on plants changes the chemical composition, the leaves pigment, and thus, changes in multiple ways the flow of photons through the leaf [44].

From the data provided by the biometric measurements it was observed that plants show different periods of growth. Plants present periods in which grow a lot, and periods when plant growth slowed. This observation was made in comparison with the data obtained during the winter, and therefore, can be mainly due to the weather (less or insufficient light, dark, cloudy sky). One should mention that the plants had the same conditions, 
watered every week, dusting and biometric measurements made weekly.

In accordance with the results of other studies by Iqbal et al. [45], for the plants maintained in polluted environment the overall plant height and number of new leaves per plant was higher (for example, the height mean values increased with 2, 1.8, and $2 \mathrm{~cm}$ for polluted Ficus elastica, Dracaena deremensis, and Sansevieria trifasci$a t a$, respectively). This may be due to the increased age of the plant and stress pollution. The modular organization of plant growth with respect to the coating architecture [46] tends to prevent extreme changes in leaf: stem reports could induce self-shading, but the plants growing in the polluted air seem to be leafier. This would be a reasonable compensatory response to air pollutant-induced losses in the photosynthetic capacity of leaves [47].

By analyzing the biometric measurements of the plants maintained in clean environment it was observed that they have normally developed. On the contrary, when the plants exposed to environmental stress were examined, it was observed, in the first phase of the plants response to stress [48], when the pollution is perceived, an increase of yellow color on leaves surface, especially at Dracaena spp., probably due to the loss of chlorophyll content in the favor of other pigments, such as carotenoids. Carotenoids i.e., alpha-carotene, beta-carotene, and xanthophyll, are present in higher concentration in leaves of plants that are either under stress, senescence or death and they support the light absorption process in plants [49]. Moreover, by examining Ficus elastica during the testing period red pigmentations of the leaves were observed, especially of new ones. The pigments related to the changing foliage are anthocyanins. Anthocyanins are red pigments that are found in abundance both in newly formed leaves and in those undergoing senescence. Anthocyanins also serve to protect the leaves from damage caused by ultraviolets [49].

In order to determine subtle alterations in the structure and biochemical composition, as a consequence of the environmental stress, FT-IR spectra were further recorded on plant material from all ornamental plants. Having in mind that leaf is the plant component that shows the greatest phenotypic plasticity in response with environmental variations, and possesses the ability to change the structure to adapt to specific environmental condition $[50,51]$ the spectra were recorded on leaf samples (see Fig. 1). By analyzing the spectra recorded from leaves of the plants maintained in clean environment one can see (curves $a$ ) the characteristic bands associated to the main functional groups. Thus, one can remark the polysaccharide fingerprint region between 1000 and $1150 \mathrm{~cm}^{-1}$, the protein region from 1500 to $1700 \mathrm{~cm}^{-1}$ and the characteristic band of $\mathrm{OH}$ stretching vibration from water around $3350 \mathrm{~cm}^{-1}$ [52]. The detailed assignment of the vibrational bands is summarized in Table II. By looking at the spectra (Fig. 1a) one can see that they are dominated by protein vibrations. More precisely, the amide I band, which is al-
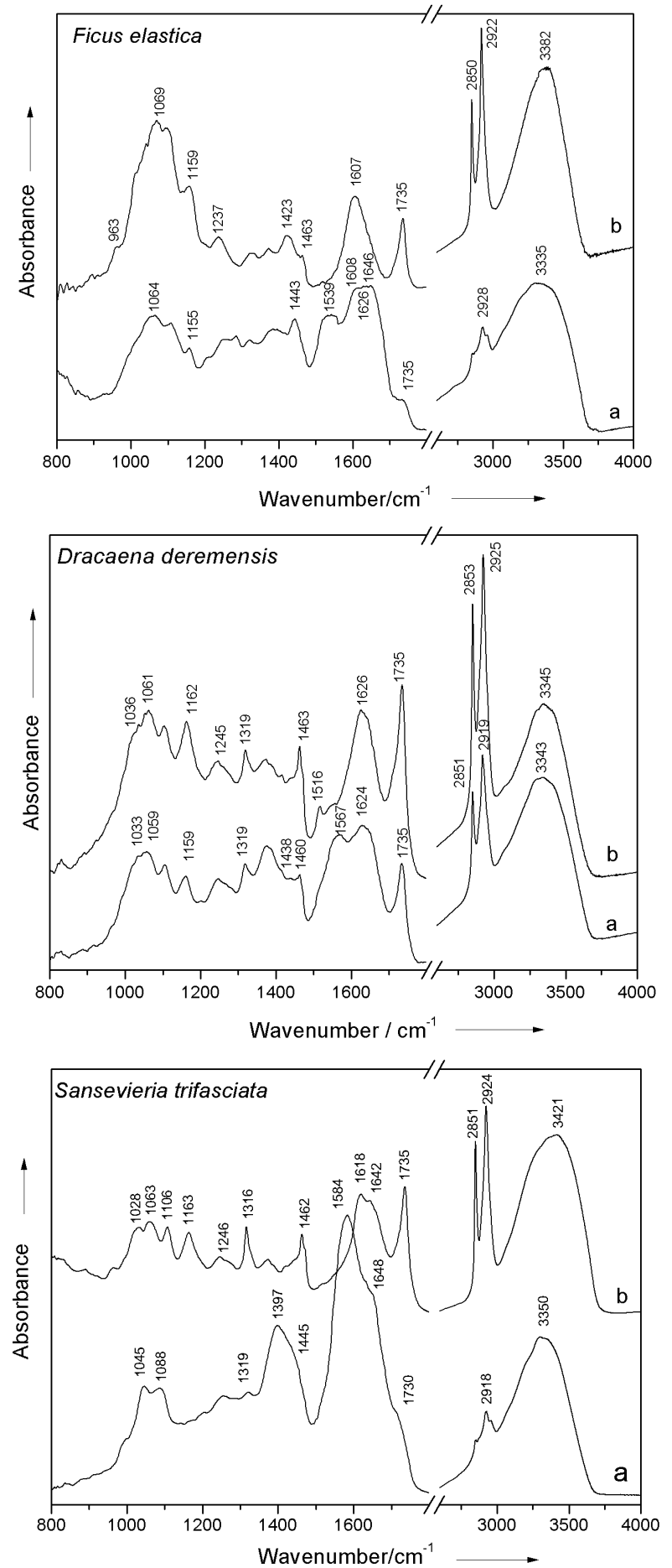

Fig. 1. FT-IR spectra of Ficus elastica, Dracaena deremensis, Sansevieria trifasciata, before $(a)$ and after exposure to environmental pollution $(b)$.

most entirely due to the carbonyl stretching vibration $\left(80 \% \mathrm{C}=\mathrm{O}\right.$ stretch) is located around $1648 \mathrm{~cm}^{-1}$ in the spectra of all samples, while the amide II band, that has a complex nature comprising both $\mathrm{NH}$ deformation and $\mathrm{CN}$ stretching vibrations $(60 \% \mathrm{~N}-\mathrm{H}$ bend and $40 \%$ C-N stretch), can be observed in the range between 1540 
and $1584 \mathrm{~cm}^{-1}$. The amide III band due to the $40 \%$ $\mathrm{C}-\mathrm{N}$ stretching and $30 \% \mathrm{~N}-\mathrm{H}$ bending vibrations, can be observed in the FT-IR spectra of all unpolluted samples at lower wavenumbers in the range between 1375 and $1397 \mathrm{~cm}^{-1}[34,53]$.

Chlorophyll is present in all samples because it is the main photoreceptor in the photosynthesis process. Katiyar and Dubey [54] point out that depending on the plant species, leaf age, level of pollution to which are exposed, and also of other biotic and abiotic conditions, chlorophyll content of plants will vary from species to species. Various studies have reported that some air pol- lutants can reduce chlorophyll content [55-57], whereas other pollutants can increase it $[14,58]$. The chlorophyll signature can be observed in the spectra of all samples maintained in clean environment. Thus, one can see the bands around 1040, 1445, 1620 and $1735 \mathrm{~cm}^{-1}$ assigned to chlorophyll $\mathrm{C}-\mathrm{C}, \mathrm{C}=\mathrm{C}$ and $\mathrm{C}=\mathrm{O}$ stretching vibrations, respectively. In the higher wavenumber range of the spectra one can also observe the absorption bands around $2850,2916 \mathrm{~cm}^{-1}$, which are due to the $\mathrm{C}-\mathrm{H}$ stretching vibrations in $\mathrm{CH}_{2}$ and $\mathrm{CH}_{3}$ groups, respectively, representative for chlorophyll, in accordance with dedicated literature [59-61].

Assignment of IR absorption bands from the unpolluted and polluted spectra of plant

TABLE II samples to the corresponding vibrational modes.

\begin{tabular}{|c|c|c|c|c|c|c|}
\hline \multicolumn{6}{|c|}{ Plant species } & \multirow{3}{*}{$\begin{array}{l}\text { Vibrational } \\
\text { assignment }\end{array}$} \\
\hline \multicolumn{2}{|c|}{ Ficus elastica } & \multicolumn{2}{|c|}{ Dracaena deremensis } & \multicolumn{2}{|c|}{ Sansevieria trifasciata } & \\
\hline unpolluted & polluted & unpolluted & polluted & unpolluted & polluted & \\
\hline $973 \mathrm{sh}$ & $963 \mathrm{~m}$ & $967 \mathrm{sh}$ & $973 \mathrm{sh}$ & & $963 \mathrm{w}$ & $\mathrm{C}=\mathrm{O}$ def pectin \\
\hline $1020 \mathrm{sh}$ & $1027 \mathrm{sh}$ & $1033 \mathrm{~m}$ & $1036 \mathrm{sh}$ & & $1028 \mathrm{~m}$ & CO str, CC str, OCH def, ring pectin \\
\hline $1038 \mathrm{sh}$ & $1042 \mathrm{sh}$ & $1042 \mathrm{sh}$ & $1052 \mathrm{sh}$ & $1045 \mathrm{~m}$ & & chlorophyll \\
\hline $1064 \mathrm{~m}$ & $1069 \mathrm{vs}$ & $1059 \mathrm{vs}$ & $1061 \mathrm{vs}$ & $1088 \mathrm{~m}$ & $1063 \mathrm{vs}$ & CO str, CC str, OCH def, cellulose \\
\hline $1104 \mathrm{~s}$ & $1097 \mathrm{~s}$ & $1101 \mathrm{~m}$ & $1103 \mathrm{~s}$ & & $1106 \mathrm{vs}$ & CO str, CC str, ring pectin \\
\hline $1155 \mathrm{~m}$ & $1159 \mathrm{~s}$ & $1159 \mathrm{~m}$ & $1162 \mathrm{vs}$ & & $1163 \mathrm{~s}$ & COC str, ring cellulose \\
\hline $1246 \mathrm{w}$ & $1237 \mathrm{~s}$ & $1246 \mathrm{~m}$ & $1246 \mathrm{~s}$ & $1245 \mathrm{w}$ & $1246 \mathrm{~m}$ & phenolic COH str of lignin \\
\hline 1320vw & $1322 \mathrm{w}$ & $1319 \mathrm{w}$ & $1319 \mathrm{~m}$ & $1319 \mathrm{w}$ & $1316 \mathrm{~m}$ & $\mathrm{CH}$ def, ring cellulose/pectin \\
\hline \multirow[t]{2}{*}{$1383 \mathrm{w}$} & $1374 \mathrm{w}$ & $1375 \mathrm{~m}$ & $1374 \mathrm{~s}$ & $1397 \mathrm{~s}$ & $1392 \mathrm{sh}$ & amide III \\
\hline & $1423 \mathrm{~m}$ & & $1417 \mathrm{w}$ & & $1426 \mathrm{sh}$ & lignin \\
\hline $1443 \mathrm{~m}$ & 1440sh & $1438 \mathrm{sh}$ & $1437 \mathrm{w}$ & $1445 \mathrm{sh}$ & & chlorophyll \\
\hline $1456 \mathrm{sh}$ & $1463 \mathrm{~m}$ & $1460 \mathrm{~m}$ & $\begin{array}{l}1463 \mathrm{~m} \\
1516 \mathrm{w}\end{array}$ & & $\begin{array}{l}1462 \mathrm{~m} \\
1516 \mathrm{w}\end{array}$ & $\begin{array}{l}\text { CH def, phenyl ring str } \\
\text { lignin }\end{array}$ \\
\hline $1539 \mathrm{~m}$ & $1546 \mathrm{sh}$ & $1567 \mathrm{~s}$ & $1569 \mathrm{sh}$ & $1584 \mathrm{vs}$ & $1582 \mathrm{sh}$ & amide II \\
\hline $1608 \mathrm{~s}$ & $1607 \mathrm{vs}$ & & & $1609 \mathrm{~m}$ & $1618 \mathrm{vs}$ & $\mathrm{C}=\mathrm{C}$ str ring lignin \\
\hline $1626 \mathrm{~s}$ & $1626 \mathrm{sh}$ & $1624 \mathrm{~s}$ & $1626 \mathrm{vs}$ & & & chlorophyll \\
\hline \multirow[t]{2}{*}{$1646 \mathrm{~s}$} & $1647 \mathrm{sh}$ & $1648 \mathrm{~s}$ & 1650sh & $1648 \mathrm{sh}$ & $1642 \mathrm{~s}$ & amide I \\
\hline & $1717 \mathrm{sh}$ & & $1713 \mathrm{sh}$ & & $1718 \mathrm{sh}$ & free fatty acids \\
\hline $1735 \mathrm{sh}$ & $1735 \mathrm{~m}$ & $1735 \mathrm{~m}$ & $1735 \mathrm{vs}$ & 1730sh & $1735 \mathrm{vs}$ & $\mathrm{C}=\mathrm{O}$ str fatty acids, chlorophyll, pectin \\
\hline \multirow[t]{2}{*}{$2851 \mathrm{sh}$} & $2850 \mathrm{~s}$ & $2851 \mathrm{~s}$ & $2853 \mathrm{vs}$ & $2851 \mathrm{sh}$ & $2851 \mathrm{vs}$ & $\mathrm{C}-\mathrm{H}$ str from $\mathrm{CH}_{2}$ \\
\hline & & $2919 \mathrm{~s}$ & & $2918 \mathrm{~m}$ & & $\mathrm{CH}$ str from $\mathrm{CH}_{3}$ \\
\hline $2928 \mathrm{w}$ & $2922 \mathrm{vs}$ & & $2925 \mathrm{vs}$ & & $2924 \mathrm{vs}$ & chlorophyll and fatty acids \\
\hline $3335 \mathrm{~s}$ & $3382 \mathrm{vs}$ & $3343 \mathrm{~m}$ & $3345 \mathrm{~s}$ & $3330 \mathrm{~m}$ & $3350 \mathrm{~s}$ & $\mathrm{OH}$ str \\
\hline
\end{tabular}

Abbreviations: $\mathrm{w}=$ weak, $\mathrm{m}=$ medium, $\mathrm{s}=$ strong, $\mathrm{sh}=$ shoulder, $\mathrm{str}=$ stretching, def = deformation.

The FT-IR spectra recorded on leaves from plants exposed to environmental stress reveal shifts to higher wavenumber values as well as changes of the relative intensities of the bands as compared to spectra recorded on test samples. This is in very good agreement with the assumption that all plants metabolism increases during the struggle with stressor existing in air.

By comparing the spectra one can see a decrease in the overall protein contribution at the amide bands (see curves $b$ ), which could be regarded as a consequence of the pollution action corroborated with the leaf senescence during the analysis period. On the other hand, the bands assigned to polysaccharide vibrations increase in the spectra recorded on polluted samples (see curves $b$ and Table II). Cosgrove [62] shown that during the development of the leaf the plant cell walls undertake secondary cell wall formation, facilitated by expansion proteins that allow for development of the cell wall by introduction of matrix polysaccharides such as cellulose, pectin, and hemi-cellulose. Moreover, it is also known that plants consume pollutants and transform them in "food" or other compounds. These, correlates with the increase of the bands around 1065 and $1160 \mathrm{~cm}^{-1}$, due to cellulose vibrations, as well as of those around 960, 1028, and $1100 \mathrm{~cm}^{-1}$ attributed to pectin vibrations. 
The analysis of the spectra recorded on polluted leaf samples further reveals that the fingerprint bands due to the fatty acids vibrations also increased. Thus, the bands around 2850 and $2922 \mathrm{~cm}^{-1}$ assigned to the symmetric and asymmetric stretching vibrations of the $\mathrm{CH}_{2}$ groups [63] are dominating the spectra recorded on all ornamental plants. Moreover, the band around $1735 \mathrm{~cm}^{-1}$, due to the stretching vibration of the $\mathrm{C}=\mathrm{O}$ bond from chlorophyll, but also from fatty acids and pectin is also enhanced in the spectra of polluted samples. The shoulder around $1713 \mathrm{~cm}^{-1}$ evidenced in the spectra of all polluted samples can be assigned to a small amount of free fatty acids.

Some other bands assigned to chlorophyll vibrations can be also observed in the spectra of the samples maintained in polluted environment (see Table II and Fig. 1b). This indicates that although these plants are subjected to pollutants they have a protective mechanism and physiological processes are not disturbed. Moreover, the bands due to water vibrations are also present in the spectra recorded on polluted leaves, fact that can be correlated with relative high water content how Nugrahani et al. [10] assert. A higher water content in the leaves of some plants help maintain their physiological balance in terms of air pollution stress, in which transpiration rates are generally higher [64, 65].

Furthermore, by analyzing the spectra an increase of the lignin content is observed that is correlated with the increased intensity of the bands assigned to lignin vibrations (see Table II and Fig. 1b). Thus, the band around $1246 \mathrm{~cm}^{-1}$ is due to the vibration of phenolic hydroxyl group of lignin [60], while the absorption band located around $1462 \mathrm{~cm}^{-1}$ is attributed to the $\mathrm{C}-\mathrm{H}$ deformation combined with aromatic ring vibration common for all lignins [66]. The band observed around 1516 and $1610 \mathrm{~cm}^{-1}$ are due to the $\mathrm{C}=\mathrm{C}$ stretching vibration of the lignin phenyl ring [53]. The presence of the lignin fingerprints bands in the spectra of all samples suggests that the plants cope with stress pollution, and the chemical components such as lignin are still functional. Lignin biosynthesis pathway is well characterized. This represents an important role in plant growth; increased cell wall integrity facilitating the transport of water and providing resistance against pathogens [67].

One should also note that no absorption signals from carotenoids or antocyanins pigments were observed in the spectra of polluted samples, proving that the plants structure is not affected by pollution. Thus, as a general remark one can affirm that all changes evidenced in the spectra recorded from plants under stress generated by pollution are in agreement with the assumption that the plants metabolism increases during the struggle with stressor existing in air.

\section{Conclusions}

In the present study the ability of three species of ornamental plants to remove chemical pollutants was evaluated, and the modifications induced by the environmental stress on the structure and biochemical composition of the plants leaves were determined by FT-IR spectroscopy. Ficus elastica, Dracaena deremensis and Sansevieria trifasciata were selected and investigated because of their ability to purify air, and their low maintenance requirements of light, the size, shape and general aesthetic qualities. The study was conducted in a real-life indoor environment, and thus, it was assessed the plant ability to remove chemical pollutants, different from those usually employed as test molecules in laboratory experiments. The main pollutant $\left(\mathrm{CO}_{2}\right)$ concentration was reduced up to $58.33 \%$, whereas the removed concentration of all other chemical pollutants was of $\approx 25 \%$, among them $28.63 \%$ for $\mathrm{O}_{3}, 25.23 \%$ for $\mathrm{SO}_{2}, 23.63 \%$ for dodecane, and $23.24 \%$ for o-xylene.

FT-IR investigations demonstrated that despite the action of chemical pollutants the plants preserved their structure by adjusting their metabolism. The higher rate of metabolism, for the plants under stress is well supported by the bands displacement to higher wavenumber up to $7 \mathrm{~cm}^{-1}$. Furthermore, a decrease in the overall protein contribution in the amide bands and an increase of the bands assigned to polysaccharide vibrations, can be regarded as consequences of the pollution action. The chlorophyll presence is also evidenced in the IR spectra of all samples by the bands around $\approx 1040$, 1445,1620 , and $1735 \mathrm{~cm}^{-1}$. The hereby presented results confirmed that FT-IR spectroscopy is a very fast and valuable method that allow for safe and rapid analysis of many valuable substances from plants in different conditions.

\section{Acknowledgments}

A. Husti expresses special thanks for financial support of this publication, which was conducted under the frame of European Social Fund, Human Resources Development Operational Programme 2007-2013, project no. POSDRU/159/1.5/S/132765.

\section{References}

[1] R. York, E.A. Rosa, Soc. Probl. 59, 282 (2012).

[2] A. Dimitriou, A. Christidou, in: The Impact of Air Pollution on Health, Economy, Environment and Agricultural Sources, Ed. M. Khallaf, InTech, Rijeka 2011, p. 215.

[3] C.J. Kibert, M.C. Monroe, A.L. Peterson, R.R. Plate, L.P. Thiele, Working Toward Sustainability: Ethical Decision-Making in a Technological World, Wiley, New Jersey 2011.

[4] D.L. Costa, in: Casarett and Doull's Toxicology: the Basic Science of Poisons, Ed. D.C. Klaassen, McGraw-Hill Medical Publ. Div., New York 2001, p. 1119.

[5] World Health Organization, Denmark: Regional Office for Europe, 2010.

[6] P. Wolkoff, Indoor Air 13, 5 (2003).

[7] M.J. Mendell, W.J. Fisk, K. Kreiss, H. Levin, D. Alexander, W.S. Cain, J. Girman, C.J. Hines, P.A. Jensen, D.K. Milton, L.P. Rexroat, K.M. Wallingford, Am. J. Public Health 92, 1430 (2002). 
[8] S. Afrin, Green Skyscraper: Integration of Plants into Skyscrapers. Degree Project, Department of Urban Planning and Environment Division of Urban and Regional Studies, 2009

[9] D.S. Yang, S.V. Pennisi, K.C. Son, S.J. Kays, HortScience 44, 1377 (2009).

[10] P. Nugrahani, E.T. Prasetyawati Sugijanto, H. Purnobasuki, Asian J. Exp. Biol. Sci. 3 298 (2012).

[11] N.H. Naveed, A.I. Batool, F.U. Rehman, U. Hameed, Afr. J. Environm. Sci. Technol. 4, 770 (2010).

[12] T. Wuytack, K. Verheyen, K. Wuyts, F. Kardel, S. Adriaenssens, R. Samson, Environm. Monit. Assess. 171, 197 (2010).

[13] F.J. Escobedo, J.E. Wagner, D.J. Nowak, C.L. Dele Maza, M. Rodriguez, D.E. Crane, J. Environm. Manage. 86, 148 (2008).

[14] P.O. Agbaire, E. Esiefarienrhe, J. Appl. Sci. Environm. Manage. 13, 11 (2009).

[15] Y.J. Liu, Y.J. Mu, Y.G. Zhu, H. Ding, N.C. Arens, Atmosph. Environm. 41, 650 (2007).

[16] R.L. Orwell, R.L. Wood, J. Tarran, F. Torpy, M.D. Burchett, Water Air Soil Poll. 157, 193 (2004).

[17] K.J. Kim, D.W. Lee, Hort. Environm. Biotechnol. 49, 132 (2008).

[18] S.C. Chun, M.H. Yoo, Y.S. Moon, M.H. Shin, K.C. Son, I.M. Chung, S.J. Kays, Kor. J. Hort. Sci. 28, 476 (2010).

[19] Y. Hasegawa, S. Asada, T. Katsube, T. Ikeguchi, IEICE Trans. Electron. 87, 2093 (2004).

[20] R.A. Wood, R.L. Orwell, J. Tarran, F. Torpy, M. Burchett, J. Hort. Sci. Biotechnol. 77, 120 (2002).

[21] M. El-Sadek, E. Koriesh, E. Fujii, E. Moghazy, Y.A. El-Fatah, Int. Res. J. Plant Sci. 3, 222 (2012).

[22] C.L. Jin, X.J. Zhou, H.T. Zhao, X.M. Liu, K. Feng, Asian J. Chem. 25, 3823 (2013).

[23] K.J. Kim, M. Il Jeong, D.WW. Lee, J.S. Song, H.D. Kim, E.H. Yoo, S.J. Jeong, S.W. Han, S.J. Kays, Y.W. Lim, H.H. Kim, Hort. Sci. 45, 1489 (2010).

[24] A. Aydogan, L.D. Montoya, Atmosph. Environm. 45, 2675 (2011).

[25] K.J. Kim, H.D. Kim, Hort. Environm. Biotechnol. 49, 155 (2008).

[26] T. Kondo, T. Jinbo, M. Onishi, K. Omasa, PhytonAnnales Rei Botanicae A 45, 477 (2005).

[27] P.J. Irga, F.R. Torpy, M.D. Burchett, Atmosph. Environm. 77, 267 (2013).

[28] K.J. Kim, E.H. Yoo, S.I. Kays, Hortscience 47, 1195 (2012).

[29] R.A. Wood, M.D. Burchett, R. Alquezar, R.L. Orwell, J. Tarran, F. Torpy, Water Air Soil Poll. 175, 163 (2006).

[30] P. Dingle, P. Tapsell, S. Hu, Bull Environm. Contam. Toxicol. 64, 302 (2000).

[31] H.H. Kim, J.Y. Lee, J.Y. Yang, K.J. Kim, Y.J. Lee, D.C. Shin, Y.W. Lim, J. Jpn. Soc. Hort. Sci. 80 96 (2011).

[32] I. Wang, Plant Omics J. 5, 508 (2012).
[33] M. Grube, O. Muter, S. Strikauska, M. Gavare, B. Limane, J. Ind. Microbiol. Biotechnol. 35, 1545 (2008).

[34] H. Schulz, M. Baranska, Vibrat. Spectrosc. 43, 13 (2007).

[35] H.L. Papinchak, E.J. Holcomb, T.O. Best, D.R. Decoteau, HortTechnology 19, 286 (2009).

[36] W. Sriprapat, P. Suksabye, S. Areephak, P. Klantup, A. Waraha, A. Sawattan, P. Thiravetyan, Ecotoxicol Environm. Saf. 102, 147 (2014).

[37] F.R. Torpy, P.J. Irga, J. Brennan, M.D. Burchett, Aerobiologia 29, 321 (2013).

[38] E. Holcman, P.C. Sentelhas, Horticultura Brasil. 31, 386 (2013).

[39] P.H. Rosso, J.C. Pushnik, M. Lay, S.L. Ustin, Environm. Poll. 137, 241 (2005).

[40] J. Krasensky, C. Jonak, J. Exp. Bot. 63, 1593 (2012).

[41] L. Taiz, E. Zeiger, Plant Physiology (Loosleaf), Sinauer Associates, USA 2010.

[42] G. Nasim, R. Bajwa, A. Hakeem, Int. J. Environm. Sci. Tech. 4, 295 (2007).

[43] C. Bowler, M. Van Montagu, D. Inze, Ann. Rev. Plant Physiol. Plant Mol. Biol. 43, 83 (1992).

[44] H.K. Lichtenthaler, F. Babani, in: Chlorophyll a Fluorescence: A Signature of Photosynthesis, Eds. G.C. Papageorgiou, Govindjee, Springer, Dordrecht 2004, p. 713 .

[45] M. Iqbal, Mahmooduzzafar, F. Nighat, P.R. Khan, J. Plant Interact. 5, 11 (2010).

[46] J. White, in: Perspectives on Plant Population Ecology, Eds. R. Dirzo, J. Sarukhán, Sinauer, Sunderland 1984 , p. 176

[47] W.E. Winner, H.A. Mooney, K. Williams, S. von Caemmerer, in: Sulfur Dioxide and Vegetation. Physiology, Ecology and Policy Issues, Eds. W.E. Winner, H.A. Mooney, R.A. Goldstein, Stanford University Press, California 1985, p. 118.

[48] H.K. Lichtenthaler, Ann. N.Y. Acad. Sci. 851, 187 (1998).

[49] A.H. El-Nahry, A.Y. Hammad, J. Appl. Sci. Res. 5 316 (2009).

[50] W.C. Dickison, Ecological Anatomy. Integrative Plant Anatomy, Harcourt Academic Press, California 2000.

[51] L. Gratani, Adv. Bot. 2014, 208747 (2014).

[52] J.A. Heredia-Guerrero, J.J. Benítez, E. Domínguez, I.S. Bayer, R. Cingolani, A. Athanassiou, A. Heredia, Front Plant Sci. 5, 305 (2014).

[53] H.J. Butler, M.R. McAinsh, S. Adams, F.L. Martin, Anal. Meth. 7, 4059 (2015).

[54] V. Katiyar, P.S. Dubey, Ind. J. Environm. Toxicol. 11, 78 (2001)

[55] P.C. Joshi, A. Swami, Environmentalist 27, 365 (2007).

[56] P.C Joshi, A. Swami, J. Environ. Biol. 30, 295 (2009).

[57] N. Joshi, A. Chauhan, P.C. Joshi, Environmentalist 29, 398 (2009). 
[58] A.K. Tripathi, M.J. Gautam, Environ. Biol. 28, 127 (2007).

[59] M.G. Geethu, P.S. Suchithra, C.H. Kavitha, J.M. Aswathy, B. Dinesh, K. Murugan, World J. Pharm. Pharmaceut. Sci. 3, 1256 (2014).

[60] M.H.M.A. Kamal, W.M.K.W.K. Azira, M. Kasmawati, Z. Haslizaidi, W.N.W. Saime, J. Environm. Sci. 22, 248 (2010).

[61] N. Ramamurthy, S. Kennan, Rom. J. Biophys. 17, 269 (2007).

[62] D.J. Cosgrove, Nat. Rev. Mol. Cell. Biol. 6, 850 (2005).

[63] A. Pednekar, B. Raman, Asian J. Pharmaceut. Clin. Res. 6, 157 (2013)
[64] M. Krishnaveni, L. Amsavalli, R. Chandrasekar, S. Durairaj, P. Madhiyan, Res. J. Pharm. Tech. 6, 537 (2013)

[65] I.C. Enete, C.E. Ogbonna, M.C. Officha, Ethiopian J. Environm. Stud. Manage. 5, 482 (2012).

[66] C.G. Boeriu, D. Bravo, R.J.A. Gosselink, J.E.G. van Dam, Industr. Crops Prod. 20, 205 (2004).

[67] N.H. Bhuiyan, G. Selvaraj, Y.D. Wei, J. King, J. Exp. Bot. 60, 509 (2009). 